Dicle Tıp Dergisi / Dicle Med J (2019) 46 (3) : 505 - 514

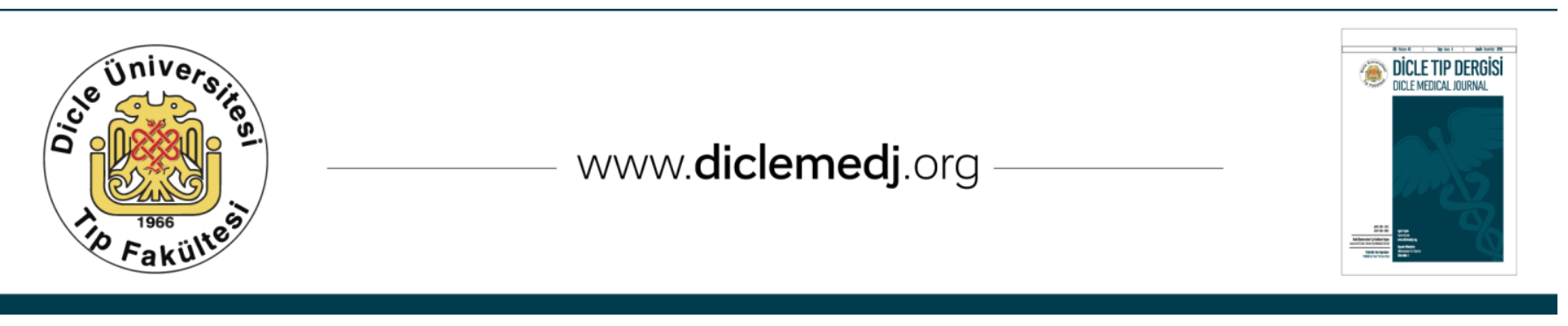

Özgün Araștırma / Original Article

\title{
Akciğer kanserinin tedavisinde periferiknöropati; Önemli bir komorbidite
}

\author{
Şenay Aydın¹, Cengiz Özdemir², Suna Aşkın Turan³, Yusuf Başer4, Murat Kıyık \\ 1 S.B.Ü. Yedikule Göğüs Hastalıkları ve Göğüs Cerrahisi Eğitim ve Araștırma Hastanesi, Nöroloji, İstanbul, Türkiye, ORCID: 0000-0003-4460-9056 \\ 2 S.B.Ü. Yedikule Gögüs Hastalıkları ve Göğüs Cerrahisi Eğitim ve Araş Hastanesi, Göğüs Hastalıkları, İstanbul, Türkiye, ORCID: 0000-0002-9816-8885 \\ 3 S.B.Ü. Yedikule Göğüs Hastalıkları ve Göğüs Cerrahisi Eğitim ve Araștırma Hastanesi, Algoloji, Istanbul, Türkiye, ORCID: 0000-0002-2397-0179 \\ 4 S.B.Ü. Yedikule Gögüs Hastalıkları ve Göğüs Cerrahisi Eğitim ve Araştırma Hastanesi, Onkoloji, İstanbul, Türkiye, ORCID: 0000-0003-3817-3823 \\ 5 S.B.Ü. Yedikule Göğüs Hastalıkları ve Göğüs Cerrahisi Eğitim ve Araș Hastanesi, Göğüs Hastalıkları, İstanbul, Türkiye, ORCID: 0000-0001-8737-1418
}

$\ddot{0} \mathbf{z}$

Amaç: Klinik pratiğimizde akciğer kanseri tedavisinde uygulanan kemoterapi rejimlerine bağlı gelişen periferiknöropatiler sık gözlenmektedir. Bu çalışmada kemoterapi tedavisi alan ve periferiknöropati gelişen akciğer kanseri tanılı hastalarda klinik semptomlar ve elektrofizyolojik bulguların değerlendirilmesi amaçlandı.

Yöntemler: Ocak 2012- Ocak 2018 tarihleri arasında nöroloji birimine konsülte edilen ve periferiknöropati ön tanısıyla elektromiyografi (EMG) incelemeleri yapılan akciğer kanseri tanıl hastaların demografik verileri, semptomları, nörolojik muayeneleri, EMG bulguları ve tedavilerinde kullanılan kemoterapi ajanları retrospektif olarak gözden geçirildi. Nöropatiye neden olabilecek diyabetesmellitus, üremi, tiroid hastalıkları ve diğer sistemik hastalıklara sahip olan hastalar çalışma dışında bırakıldı.

Bulgular: 371 (315, Erkek) hasta çalışmaya dahil edildi. Hastaların 203'ünde (\%54,7) pozitif duyusal, 247'inde $(\% 66,6)$ negatif duyusal, 81'inde $(\% 21,8)$ motor semptomlar ve 127 'inde $(\% 34,2)$ ağrl semptomları mevcuttu. EMG ile saptanan polinöropati varlığına göre hastalar polinöropati olanlar Grup I (n:250, \%67,4) ve olmayanlar Grup II (n:121, \%32,6) olarak sinıflandırıldı. Grup I' de, 160 hastada (\%43,1) duyusal, 5 hastada (\%1,3) motor, 85 hastada $(\% 22,9)$ duyusal ve motor liflerin birlikte etkilendiği polinöropati varlı̆̆ saptandı. Grup I' de negatif duyusal semptomlar ile motor semptomlar, Grup II 'de dizestezi ve parestezi semptomları istatistiksel anlamlılıkta yüksek oranda gözlendi ( $\mathrm{p}=0.001, \mathrm{p}=0.001, \mathrm{p}=0.001, \mathrm{p}=0.001)$.

Sonuç: Akciğer kanseri tedavisinde uygulanan kemoterapi rejimlerine bağlı gelişen periferiknöropatilerde en sık duyusal semptomlar gözlenmekte ve kemoterapi ajanına göre motor semptomlarda artış gözlenebilmektedir.

Anahtar kelimeler: Akciğer kanseri, elektromiyografi, duyusal semptomlar, kemoterapi rejimleri, toksiknöropatiler

DOI: 10.5798/dicletip.620534

Yazışma Adresi / Correspondence: Senay Aydın, Yedikule Göğüs Hastalıkları ve Göğüs Cerrahisi Eğitim ve Araştırma Hastanesi, Nöroloji, 34020, Zeytinburnu-İstanbul, Türkiye e-mail: aydin.senay@hotmail.com 


\title{
Peripheral neuropathy in the treatment of lung cancer; an important comorbidity
}

\begin{abstract}
Objective: In our clinic practice, peripheral neuropathies due to chemotherapy regimens in the treatment of lung cancer are frequently observed. The aim of this study was to evaluate the clinical symptoms and electrophysiological findings of chemotherapy administered patients with lung cancer who developed peripheral neuropathy.

Method: The demographic data, symptoms, neurological examinations, EMG findings and chemotherapy agents of the lung cancer patients who were consulted to the neurology department between January 2012 and January 2018 and underwent electromyography (EMG) examinations with the preliminary diagnosis of peripheral neuropathy were reviewed retrospectively. Patients with diabetes mellitus, uremia, thyroid diseases and other systemic diseases that may cause neuropathy were excluded from the study.

Results: Three hundred seventy-one (315, male) patients were included in the study. Of these patients, 203 (54.7\%) had positive sensory, 247 (66.6\%) negative sensory, 81 (21.8\%) motor symptoms and 127 (34.2\%) had pain symptoms. According to the presence of polyneuropathy detected by electromyography, patients with polyneuropathy were classified as Group I (n: 205, 67.4\%) and those without polyneuropathy as Group II (n: 121, $32.6 \%)$. In Grup I, we detected sensory polyneuropathy in 160 patients (43.1\%), motor polyneuropathy in 5 patients $(1.3 \%)$ and sensory - motor polyneuropathy in 85 patients $(22.9 \%)$. It was observed that presence of motor symptoms and negative sensory symptoms in Group I and presence of dysesthesia and paresthesia symptoms in Group II were statistically significant higher II ( $\mathrm{p}=0.001, \mathrm{p}=0.001, \mathrm{p}=0.001, \mathrm{p}=0.001$ ).

Conclusion: Sensory symptoms are the most common symptoms in chemotherapy induced polyneuropathy for lung cancer, and an increase in motor symptoms can be observed depending on the chemotherapy agent.
\end{abstract}

Keywords: Lung cancer, electromyography, chemotherapy treatments, sensory symptoms, toxic neuropathies.

\section{GíRiş}

Kemoterapi rejimlerine bağlı gelişen toksiknöropatiler klinik pratikte sık gözlenmektedir. Hastalarda duyusal, motor ya da her iki modaliteyi içeren kalın liflerin ya da ince liflerin etkilendiği daha çok aksonal tipte polinöropati izlenebilir. Toksik periferik nöropatiler çoğunlukla uzun aksonlarda gelişir ve eldiven-çorap tarzı his kusuru ile prezente olur. Duysal aksonal nöropatiler en sik karşılașılan formu oluşturur ${ }^{1,2}$. Bu hastalarda özellikle nöropatik ağrı birlikteliği en büyük problemlerden biridir ${ }^{3,4}$. Duyusal ve motor periferikpolinöropatiye neden olabilecek tedaviler arasinda platinum (oxaliplatin, cisplatin vb), vinka alkoloidleri (vincristine and vinblastine), epothilone (ixabepilone) ve taksan grupları (paclitaxel, docetaxel), proteasome inhibitörleri (bortezomid) ve immümmodulatörler (thalidomide) yer almaktadır ${ }^{5,6}$. Kemoterapötik ajanın özelliğine göre ağırlıklı etkilenen lif tipi değişebilir ve etkilenen life bağlı klinik değişkenlik gözlenebilir7-9. Nöropati oluşumunda hem kemoterapötik ajan, hem de ajanın kümülatif doz etkisi önemlidir ${ }^{10,11}$. Ayrıca tedavi öncesinde özellikle nöropati gelişimine katkıda bulunabilecek diyabetesmellitus ve diğer kronik hastalıkların birlikteliği de bu riski arttırabilmektedir ${ }^{12}$. Bu hastalar için klinik takip büyük önem kazanmaktadır. Özellikle kanser tedavisi uygulayan merkezlerde her seansta hasta semptomlarının sorgulanması erken tanı için son derece önemlidir.

$\mathrm{Bu}$ çalışmada akciğer kanseri nedeniyle kemoterapi tedavisi alan ve periferiknöropati gelişen hastalarda klinik semptomlar ile elektrofizyolojik bulguların değerlendirilmesi amaçlandı. 


\section{YÖNTEMLER}

$\mathrm{Bu}$ kesitsel tanımlayıcı çalışmada üçüncü basamak bir eğitim ve araştırma hastanesinden elde edilen veriler retrospektif olarak değerlendirildi. Ocak 2012-Ocak 2018 tarihleri arasında Nöroloji Kliniğine nöropati ön tanısıyla konsülte edilen ve elektromiyografi (EMG) incelemeleri yapılan akciğer kanseri tanılı olguların demografik verileri, semptomları, nörolojik muayene bulguları, elektrofizyolojik verileri ve aldıkları kemoterapi ajanları incelendi. Çalışma için klinik araştırmalar etik kurulundan (2018/1490) izin alındı.

Nöropatiye neden olabilecek diyabetesmellitus, üremi, tiroid hastalıkları ve diğer sistemik hastalıklara sahip olan hastalar çalışma dışında bırakıldı. Polinöropati ön tanısı ile laboratuvarda yapılan EMG incelemesinde üst ekstremitede sağ medyan ve ulnar sinir duyusal ve motor yanıtları, alt ekstremitede sağ peroneal ve tibial sinir motor yanitları ile iki yanlı sural sinir duyusal yanitları ve $\mathrm{H}$ refleks kayıtlarından oluşan standart EMG protokolü uygulanmış olan hastalar çalışmaya dahil edildi. Hastaların demografik verileri ve nörolojik muayene bulguları, poliklinik ve EMG laboratuvarı kayıtlarından retrospektif olarak analiz edildi. Klinik bulguları ve EMG verileri kaydedilmiş olan hastaların yaş, cinsiyet, başvuru semptomları, başvuru sırasında yapılan nörolojik muayeneleri, kullanılan kemoterapi ajanları ve EMG bulguları kaydedildi.

Tüm hastaların semptomları negatif duyusal, pozitif duyusal, motor, dizestezi, parestezi ve ağrı varlığına göre sınıflandırıldı. Hastaların duyusal semptomları spesifik uyarı kaynaklı bulguların varlığı ve yokluğu göre sınıflandırıldı. Basit nörolojik testleri içeren muayene bulgularında hiperestezi, hiperaljezi, allodini gibi pozitif duyusal bulguların varlığı, hipoestezi veya hipoaljezi gibi negatif duyusal bulguların varlığı ile herhangi bir uyaran olmaksızın oluşan dizestezi (ağrılı his) ya da parestezi (ağrısız his) varlı̆̆ı incelendi. Nörolojik muayenelerinde derin ve yüzeyel duyu kusurları, kas gücü kayıpları ve patalojik serebellar bulguları kaydedildi. Nörolojik muayenelerinde kas gücü kayıpları Medical Research Council (MRC) skalası ile belirlendi ${ }^{13}$.

\section{İstatistik}

İstatistiksel analiz için SPSS 22.0 (IBM Corp. Released 2013. IBM SPSS Statisticsfor Windows, Version 22.0. Armonk, NY) kullanıldı. Tüm elde edilen verilerin minimum, maksimum, median, ortalama standart deviasyon, sıklık ve yüzde değerleri hesaplandı. Ortalamaların karşılaştırılmasında nonparametrik değerler için Mann-Whitney U testi ve parametrik değerler için T testi kullanıldı. Kategorik değişkenlerin analizinde ki-kare testi kullanıldı. İstatistiksel anlamlılık düzeyi $p<0,05$ olarak alındı.

\section{BULGULAR}

Ocak 2012-Ocak 2018 tarihleri arasında nöroloji polikliniğinde akciğer kanseri tanısı olan ve nöropati kliniği ile başvuran 783 hasta saptand. $\mathrm{Bu}$ hastaların 99' unda diyabetesmellitus öyküsü, 53' ünde tedavi sırasında ortaya çıkmış ve sonrasında da tedavi ihtiyacı doğan hiperglisemi varlığı, 19'unda tiroid fonksiyon bozukluğu öyküsü mevcuttu. Ayrica 241 hastada eksik veri olması nedeniyle toplam 412 hasta verisi çalışmadan çıkarıldı. Çalışmaya 31-77 (62 \pm 8,59) yaş aralığında 315'i (\%84,9) erkek, 56'sı $(\% 15,1)$ kadın toplam 371 hasta dahil edildi. EMG ile saptanan polinöropati bulgularına göre hastalar polinöropati olanlar Grup I (n:250, \%67,4), olmayanlar Grup II (n:121, \%32,6) olarak sinıflandirıldı (Tablo 1). Grup I' de 160 (\%43,1) hastada duyusal, $5(\% 1,3)$ hastada motor, 85 $(\% 22,9)$ hastada duyusal ve motor liflerin birlikte etkilendiği mixt tip polinöropati mevcuttu. Grup II' de 71 olguda normal EMG bulguları belirlendi (Tablo 2). 
Tablo 1. Olguların demografik, semptom ve nörolojik muayene bulguları

\begin{tabular}{|c|c|c|c|c|c|}
\hline & \multirow[b]{4}{*}{$\begin{array}{r}\text { Grup I (n; \%) } \\
\text { Grup II (n; \%) } \\
\text { p }\end{array}$} & Toplam & \multicolumn{2}{|c|}{ Cinsiyet } & \multirow[b]{2}{*}{$\mathrm{p}$} \\
\hline & & \multirow[b]{2}{*}{371} & Erkek & Kadın & \\
\hline & & & $315 ; \% 84,9$ & $56 ; \% 15,1$ & $0,001^{*}$ \\
\hline & & $\begin{array}{c}250 ; \% 67,4 \\
121 ; \% 32,6 \\
0,001^{*}\end{array}$ & $\begin{array}{c}219 ; \% 87,6 \\
96 ; \% 79,3\end{array}$ & $\begin{array}{l}31 ; \% 12,4 \\
25 ; \% 20,7\end{array}$ & 0,067 \\
\hline Yaş, ort $\pm S D$ (min-max) & $\begin{array}{r}\text { Grup I } \\
\text { Grup II } \\
\text { p }\end{array}$ & $\begin{array}{c}62 \pm 8,59(31-77) 63,87 \pm 7,53 \\
58,21 \pm 9,37 \\
0,001^{*}\end{array}$ & $62,29 \pm 8,43$ & $60,51 \pm 9,37$ & 0,189 \\
\hline \multicolumn{6}{|l|}{ Semptom, (n; \%) } \\
\hline & $\begin{array}{l}\text { Duyusal Pozitif } \\
\text { Duyusal Negatif }\end{array}$ & $\begin{array}{l}203 ; \% 54,7 \\
247 ; \% 66,6\end{array}$ & $\begin{array}{l}175 ; \% 55,6 \\
207 ; \% 65,7\end{array}$ & $\begin{array}{l}28 ; \% 50,0 \\
40 ; \% 71,4\end{array}$ & $\begin{array}{l}0,442 \\
0,404\end{array}$ \\
\hline & Motor & $81 ; \% 21,8$ & $68 ; \% 21,6$ & $13 ; \% 23,2$ & 0,576 \\
\hline & Ağrl & $127 ; \% 34,2$ & $106 ; \% 33,7$ & $21 ; \% 37,5$ & 0,786 \\
\hline & Dizestezi & $181 ; \% 48,8$ & $157 ; \% 49,8$ & $24 ; \% 42,9$ & 0,335 \\
\hline & Parestezi & $191 ; \% 51,5$ & $164 ; \% 52,1$ & $27 ; \% 48,2$ & 0,595 \\
\hline \multicolumn{6}{|c|}{ Nörolojik Muayene, (n; \%) } \\
\hline & Yüzeyel Duyu & $216 ; \% 58,2$ & $190 ; \% 60,3$ & $26 ; \% 46,4$ & 0,052 \\
\hline & Derin Duyu & $138 ; \% 37,2$ & $115 ; \% 36,5$ & $23 ; \% 41,1$ & 0,515 \\
\hline & Motor & $75 ; \% 20,2$ & $63 ; \% 20,0$ & $12 ; \% 21,4$ & 0,806 \\
\hline & Serebellar & $102 ; \% 27,5$ & $90 ; \% 28,6$ & $12 ; \% 21,4$ & 0,270 \\
\hline
\end{tabular}

Grup I: EMG ile saptanan polinöropati olguları

Grup II: Nöropati semptomu olup elektormiyografik olarak polinöropati saptanamayan olgular ${ }^{*} \mathrm{p}<0,05$; İstatistiksel düzeyde anlamlı olarak kabul edildi.

Çalışmaya dahil edilen olgularda cinsiyet ile yaş, başlangıç semptomları ve nörolojik muayene bulguları arasinda anlamlı fark gözlenmedi (Tablo 1). Grup I' de negatif duyusal semptomlar ile motor semptomlar, Grup II 'de dizestezi ve parestezi semptomları istatistiksel anlamlılıkta yüksek oranda gözlendi ( $\mathrm{p}=0.001, \mathrm{p}=0.001, \mathrm{p}=0.001, \mathrm{p}=0.001$ ) (Tablo 2). Pozitif duyusal ve ağrı semptomları açısından gruplar arasında anlamlı fark saptanmadı ( $\mathrm{p}=0.399, \mathrm{p}=0.740)$ (Tablo 2). Diğer taraftan derin duyu kusuru saptanan olgular Grup II' de anlaml derecede daha yüksekti (n:58; \%47,9; p=0,003) (Tablo 3).

Nöropati semptomları arasında en sik gözlediğimiz negatif duyusal semptomlara sahip olguların (n:247, \%65,0) nörolojik muayenelerinde yüzeyel ve derin duyu kusuru bulguları yüksek oranda gözlendi. Ayrıca istatistiksel olarak anlamlı olmasa da ataksi, dismetri gibi serebellar sistem bulguları en yoğun bu grupta saptandı (n:72, \%29,1; $\mathrm{p}=0,313$, Tablo 3). Elektrofizyolojik olarak ise en sık saf duyusal tip polinöropatinin eşlik ettiği gözlendi (Tablo 2).

Pozitif duyusal semptom 203 hastada gözlendi. Nörolojik muayenelerinde belirgin olarak yüzeyel duyu kusuru ön planda olmakla birlikte pozitif duyusal semptomu olmayan gruba göre karşılaștırıldığında motor bulgular anlamlı ölçüde daha fazla idi $(p=0,001)$ (Tablo 3). 
Tablo 2. Semptomların EMG bulgularına göre değerlendirilmesi

\begin{tabular}{|c|c|c|c|c|c|c|c|}
\hline & \multicolumn{7}{|c|}{ Semptom, (n; \%) } \\
\hline & $\begin{array}{c}\text { Duyusal } \\
\text { Pozitif }\end{array}$ & DuyusalNegatif & Motor & Ağrı & Dizestezi & Parestezi & Toplam \\
\hline \multicolumn{8}{|l|}{ Polinöropati varlığı, } \\
\hline Grup II & $70 ; 57,9 \%$ & $58 ; 47,9 \%$ & $10 ; 8,3 \%$ & $40 ; 33,1 \%$ & $89 ; 73,6 \%$ & $79 ; 65,3 \%$ & $121 ; 32,6 \%$ \\
\hline $\mathrm{p}$ & 0,399 & $0,001^{*}$ & $0,001^{*}$ & 0,740 & $0,001^{*}$ & $0,003^{*}$ & \\
\hline \multicolumn{8}{|l|}{ Grup I } \\
\hline \multicolumn{8}{|l|}{ Grup II } \\
\hline Normal & $38 ; 18,7 \%$ & $40 ; 16,2 \%$ & 0 & $9 ; 7,1 \%$ & $54 ; 28,7 \%$ & $57 ; 29,8 \%$ & $71 ; 27 \%$ \\
\hline NMKH & $4 ; 2,0 \%$ & 0 & $6 ; 7,4 \%$ & $2 ; 1,6 \%$ & $4 ; 3,3 \%$ & 0 & $6 ; 1,6 \%$ \\
\hline Radikülopati & $5 ; 2,5 \%$ & $5 ; 2,0 \%$ & $4 ; 4,9 \%$ & $5 ; 3,9 \%$ & $4 ; 2,2 \%$ & $2 ; 1,0 \%$ & $5 ; 1,3 \%$ \\
\hline TuzakNöropatisi & $13 ; 6,4 \%$ & $11 ; 4,5 \%$ & 0 & $14 ; 11,0 \%$ & $11 ; 6,1 \%$ & $10 ; 5,2 \%$ & $18 ; 4,9 \%$ \\
\hline H refleks değissikliği & $10 ; 4,9 \%$ & $2 ; 0,8 \%$ & 0 & $10 ; 7,9 \%$ & $16 ; 8,8 \%$ & $8 ; 4,2 \%$ & $21 ; 5,7 \%$ \\
\hline
\end{tabular}

Grup I: EMG ile saptanan polinöropati olguları,

Grup II: Nöropati semptomu olup elektormiyografik olarak polinöropati saptanamayan olgular

PNP; Polinöropati

${ }^{*} \mathrm{p}<0,05$; İstatistiksel düzeyinde anlamlı olarak kabul edildi.

Motor bulgular özellikle alt ekstremite distallerinde ve MRC skalasına göre -5/5 ile 4/5 arasında hafif oranda idi. İstatistiksel olarak anlaml olmamakla birlikte bu grupta saf duyusal ve mixt tip polinöropati daha sık olarak saptandı (Tablo 2).

Sadece güçsüzlük semptomu ile başvuran 81 hastanın \%92,6' inda (n:75) muayenelerinde özellikle alt ekstremite ve distal hakimiyetli MRC skalasına göre $0 / 5$ ile $-5 / 5$ arasında değişik derecelerde kas gücü kaybı mevcuttu. Ayrıca başvuru semptomları arasında belirgin olmamasına rağmen hastaların nörolojik muayenelerinde \%39,5' unda (n:32) yüzeyel duyu kusuru, \%16,0' inda (n:13) derin duyu kusuru ve \%14,8' inde (n:12) patolojik serebellar bulgular mevcuttu. Ağrı şikayetinin belirgin olduğu hastalarda (n:127; \%34,2) nörolojik muayenelerinde özellikle alt ekstremitelerde belirgin kas gücü kaybının eşlik ettiği motor bulguların istatistiksel anlamlılıkta belirgin olduğu ( $\mathrm{p}=0,001$, Tablo 3 ) ve EMG'de sıklıkla mixt tip polinöropati varlığı gözlendi.

Hastaların 81' inde $(\% 48,8)$ dizestezi ve 191' inde $(\% 51,5)$ parestezisi saptand. Dizestezisi olan hastaların nörolojik muayenelerinde istatistiksel olarak anlamlı ölçüde derin duyu kusuru belirgindi (n:81; \%42,6, p=0,026) (Tablo 3). Ayrica duyusal ve motor semptom varlığl yaş ve cinsiyet açısından karşılaştırıldığında istatistiksel olarak anlamlı bir fark saptanmadı (Tablo 4).

Hastaların çoğunda (n:354, \%95,4) kombinasyon tedavisi mevcuttu. Kemoterapi rejimleri arasinda Cisplatin- Vinorelbine (n:47, \%12,7), Cisplatin- Doketaksel (n:82, \%22,1), Cisplatin- Etoposide (n:55, \%14,8), CisplatinGemsitabine (n:25, \%6,7) ve PaklitaxelCarboplatin (n:145, \%39,1) kombinasyon tedavileri mevcuttu. Ayrıca hastaların çoğunda (n:226, \%60,9) tedavide Cisplatin yer almaktayd. Nöropati semptomu olan ve EMG ile kalın lif tutulumu saptanan $250(\% 67,4)$ hastadan 160'ında (\%43,1) saf duyusal, 85'inde $(\% 22,9)$ ise mixt tip polinöropati saptand (Tablo 5).

\section{TARTIŞMA}

$\mathrm{Bu}$ çalışmada akciğer kanseri tanılı olgularda kemoterapi tedavisi sonrası gelişen toksiknöropatilere sahip olgular klinik ve elektrofizyolojik açıdan değerlendirildi. Tüm olgularda en sik başvuru semptomu duyusal semptomlardı. Elektrofizyolojik veriler, negatif 
duyusal semptomların belirgin olduğu hasta grubunda saf duyusal, motor semptomların belirgin olduğu grupta ise hem duyusal hem de motor liflerin etkilendiği mikst tip polinöropati varlığınının ön planda olduğunu gösterdi.
Elektrofizyolojik olarak polinöropati saptanan olgularda negatif duyusal ve motor semptomlar, saptanmayan grupta ise dizestezi ve parestezi semptomları istatistiksel anlamlılıkta yüksek oranda saptandı.

Tablo 3. Nörolojik muayene bulguları ve semptom karșılaștırılması

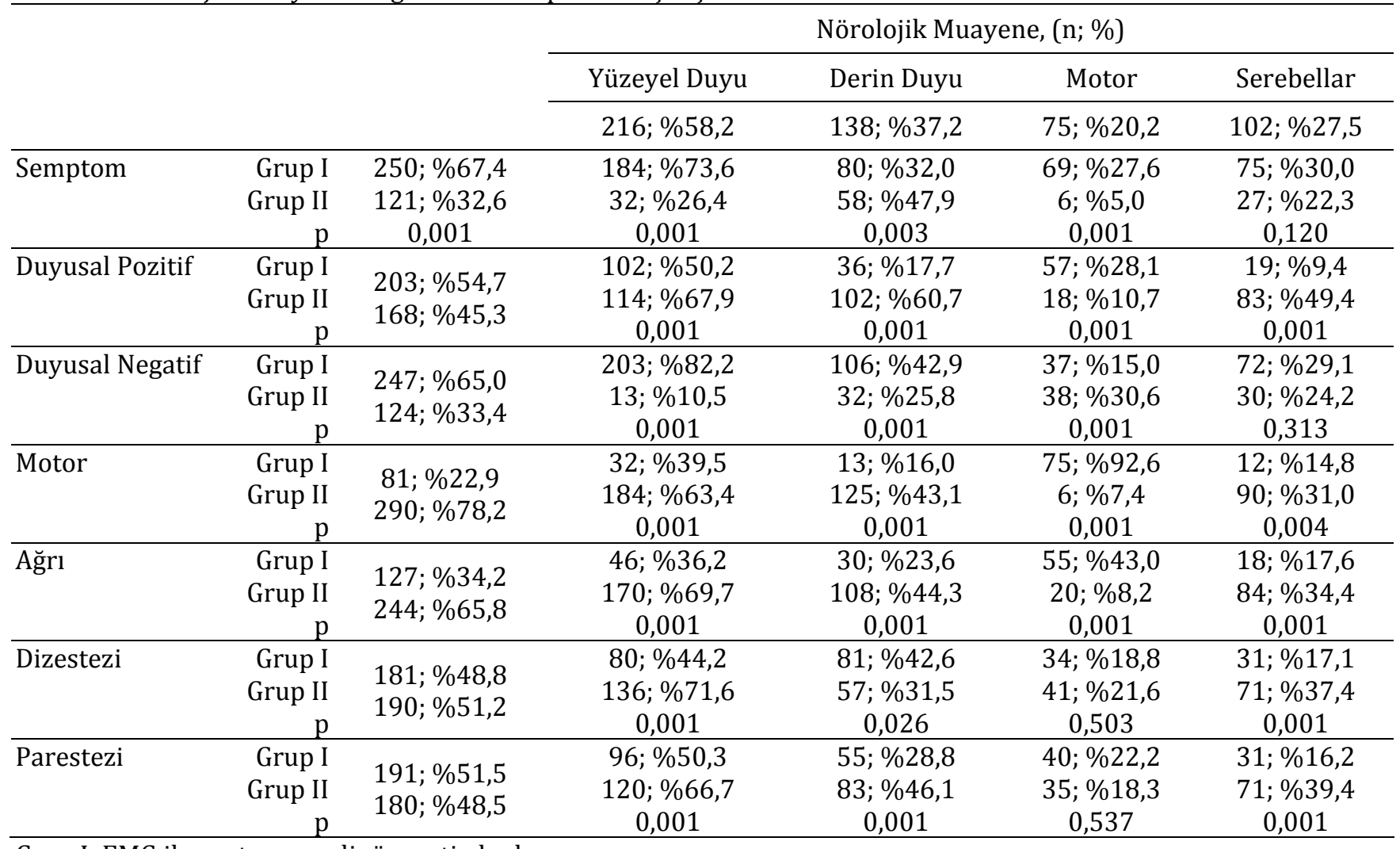

Grup I: EMG ile saptanan polinöropati olguları,

Grup II: Nöropati semptomu olup elektormiyografik olarak polinöropati saptanamayan olgular

${ }^{*} \mathrm{p}<0,05$; İstatistiksel düzeyinde anlamlı olarak kabul edildi.

Kemoterapi ilişkili toksiknöropati semptomları sıklıkla duyusaldır ${ }^{14}$. Çoğunlukla duyusal lifler etkilendiği için, parestezi, dizestezi, duyusal ve derin duyu kaybı ve ağrı gibi yakınmalar belirgindir. Özellikle nörotoksik ajanlara karşı korunmasız olduğu düşünülen uzun lifli duyusal aksonlarda ekstremitedistalindenörotoksik hasara bağlı olarak eldiven çorap tarzında duyusal kusur ile karşımıza çıkmaktadır ${ }^{15,16}$. Bu çalışmada olguların çoğunda duyusal semptomlar ön planda olup, EMG incelemelerinde saf duyusal ve mixt tip polinöropati mevcuttu. Özellikle uyuşma ve karıncalanma gibi duyusal semptom varlığı düşme riskini önemli oranda arttırmakta ve yaşam kalitesini düşürmektedir. Ayrıca ağır vakalarda, bu semptomlar duyusal algılamanın kaybolmasına yol açabilecek şekilde progrese olabilir ve gelişen derin duyu kusurları ve denge kayıpları düşme riskini arttırabilir ${ }^{17-19}$. Olgularımızda da derin duyu kusuru ve ataksi sık olarak gözlendi. Özellikle Grup II' de derin duyu kusuru anlamlı ölçüde belirgin olup bu hastalarda negatif duyusal semptomlar da sıkt.. Duyusal semptom ya da muayene ile saptanan duyusal kusurlar her zaman elektrofizyolojik olarak kayıt altına alabilmek mümkün olamamaktadır. Özellikle inceleme alanı dışında 
kalan anatomik yapılardaki tutulumu olgulardaki derin duyu kusuru veya ince lif gösterebilmek için daha kapsamlı incelemelere nöropatisini ortaya koyabilecek ihtiyaç bulunmaktadır. Retrospektif olarak elektrofizyolojik bilgilere ulaşılamamıştır. verilerin değerlendirildiği bu çalışmada

Tablo 4. Semptomların yaș ve cinsiyet açısından karșlaștırılması

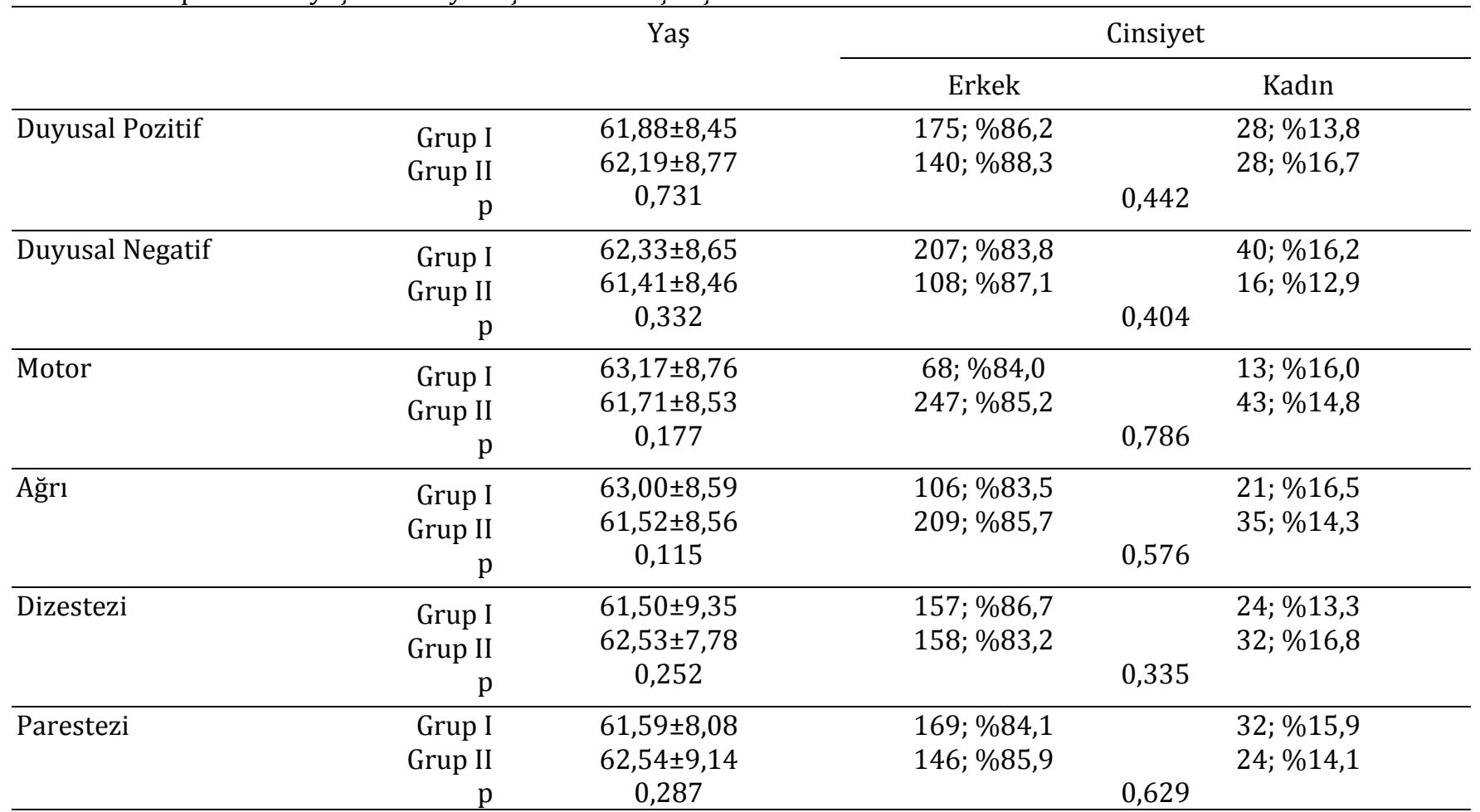

Grup I: EMG ile saptanan polinöropati olguları,

Grup II: Nöropati semptomu olup elektormiyografik olarak polinöropati saptanamayan olgular

${ }^{*} \mathrm{p}<0,05$; İstatistiksel düzeyinde anlamlı olarak kabul edildi.

Kemoterapi ilişkili toksiknöropati gelişimi kullanılan ajana bağlı olarak \%30-70 arasında değişmektedir. Ajanın türü dışında kümülatif dozu ve birden fazla ajanın kombine uygulanımınöropati riskini arttırmaktadır ${ }^{1,2}$. Histopatolojik olarak genellikle kalın miyelinli liflerde değişiklikler gözlenir,2,79. Çoğunlukla duyusal semptomların belirgin olduğu olgular ile birlikte, motor semptomlar ciddi fonksiyonel disabiliteye neden olabilecek boyutta olabilir ${ }^{20}$. Taksan, platinum ve vinkaalkoloidleri en sik kemoterapi ilişkili toksiknöropati ile ilişkilendirilen ajanlar içinde yer almaktadır ${ }^{5,6}$. Cisplatin kaynaklı kemoterapi ilişkili toksiknöropatide çoğunlukla mikst tip nöropati gözlenir. Tat ve vibrasyon kaybı, parestezi, güçsüzlük ve tremor sıklıkla gözlenen bulgular arasındadır ${ }^{11}$. Toksiknöropatide motor liflerin etkilenmesi daha yüksek dozlarda ve nadir olarak gözlenmektedir. Motor bulgular arasında distal güçsüzlük, yürüme ve denge bozuklukları ve ince hareketlerde bozulma gözlenebilir ${ }^{11}$. Motor yetmezlik ilerleyebilir ve belirgin fonksiyonel kayıplara neden olabilir ${ }^{20}$ Tedavide taksan gruplarının yüksek dozda kullanılımı özellikle distalhakimiyetli kas krampları ve ağrının eşlik ettiği motor ve otonomikdisfonksiyon gelişimini arttırmaktadır ${ }^{4,11}$. Olgularımızda motor semptom varllğg literatüre göre daha yüksek oranda (n:81, \%21,8) olup, bu grupta hastaların $\% 87,6$ 'ında elektrofizyolojik olarak mikst tip ya 
da pür motor polinöropati varlığı mevcuttu. Yine bu grupta ağrı ve derin duyu kusurları görece daha sı gözlenmekteydi. Kemoterapötik ajanın özelliğine göre ağırlıklı etkilenen lif tipi değişebilir ve klinik değişkenlik gözlenebilir ${ }^{21-25}$. Akciğer kanseri tedavi rejimlerinde sıklıkla yer alan cisplatin ve taxel kullanımının bizim olgularımızda belirgin olması literatüre oranla daha yüksek oranda saptadığımı motor semptomları ve bu olgularda daha sık saptanan derin duyu kusurları ve ağrı varlığını açıklamaktadır.

Tablo 5. Kemoterapi ajanları ile elektofizyolojik verilerin karșılaștırılması

\begin{tabular}{lccccc}
\hline & Grup I & \multicolumn{2}{c}{ Grup II } & Total \\
\hline Paklitaxel + Carboplatin & $\mathrm{N}$ & Duyusal & Mikst & Motor & \\
\hline Cisplatin + Doketaksel & $56(38,6)$ & $65(44,8)$ & $23(15,9)$ & $1(0,7)$ & $145(39,1)$ \\
\hline Cisplatin + Etoposide & $31(37,8)$ & $30(36,6)$ & $20(24,4)$ & $1(1,2)$ & $82(22,1)$ \\
\hline Cisplatin + Vinorelbine & $4(7,3)$ & $37(67,3)$ & $13(23,6)$ & $1(1,8)$ & $55(14,8)$ \\
\hline Cisplatin + Gemsitabine & $13(27,7)$ & $16(34,0)$ & $17(36,2)$ & $1(2,1)$ & $47(12,7)$ \\
\hline Cisplatine & $12(48,0)$ & $6(24,0)$ & $7(28,0)$ & 0 & $25(6,7)$ \\
\hline & $5(29,4)$ & $6(35,3)$ & $5(29,4)$ & $1(5,9)$ & $17(4,6)$ \\
\hline
\end{tabular}

Grup I: EMG ile saptanan polinöropati olguları,

Grup II: Nöropati semptomu olup elektormiyografik olarak polinöropati saptanamayan olgular

Kanser tedavisini takiben önemli bir komorbidite nedeni olan periferik nöropatiler çoğunlukla ağrılı olabilir ve yaşam kalitesinde ciddi azalmaya neden olabilmektedir ${ }^{25}$. Nöropati gelişmeden özellikle kür dönemlerinde kavşak kaslarında belirgin akut ağrı sendromu sı gözlenmektedir ${ }^{24}$. Olgularımızın \%34,2 (n:127)'inde tedavinin devam ettiği dönmede belirgin nöropatik ağrı varlığı saptandı. Bu grupta özellikle alt ekstremitelerde belirgin parezinin eşlik ettiği mixt tip polinöropati mevcuttu. Ağrı semptomlarının daha geri planda olması Monfort ve arkadaşlarının da belirttiği gibi terminoloji ile ilgili olabilir ki çoğu zaman yanma, donma, batma, karıncalanma gibi semptomlar ağrıdan ziyade sensorial olarak tanımlanmaktadır ${ }^{27}$. Ağırlıklı olarak C liflerinin hasarında gelişen ağrı, dizestezi ve parestezi gibi semptomlar daha çok klinik değerlendirme ile belirlenebilir. Bizim çalışmamızda da EMG bulguları normal sınırda değerlendirilen olgularda dizestezi ve parestezi görülme oranı daha yüksekti. $\mathrm{Bu}$ hastalarda nöropati takibinde EMG'nin tek başına yeterli olmayacağını ve özellikle klinik semptom ve nörolojik muayenenin önemini göstermektedir.

Retrospektif kesitsel tanımlayıcı olan bu çalışmanın en önemli limitasyonu olası paraneoplastik polinöropatilerin dışlanamamasıdır. Akciğer kanserinde eşlik eden paraneoplastik sendromlar içerisinde periferik nöropatiler literatürde sıklıkla vaka bazında bildirilmiştir ${ }^{28,29}$. Özellikle kemoterapi tedavisi ile birlikte nöropati semptomu gelișen hastalar çalıșmaya alınmış olsa da paraneoplastik nöropatilerin retrospektif veriler ile ayırt edilmesi mümkün olamayabilir.

Sonuç olarak kemoterapiye bağlı nöropati farklı lifleri etkileyebilmekte ve farklı klinik tablolar ile karşımıza çlkabilmektedir. Henüz bilinen hiçbir önleyici veya iyileştirici tedavi bulunmamaktadır. Klinik semptomların tedavi süresince takibi nöropatinin erken dönemde 
saptanmasını, önlemlerin erken dönemde alınmasını sağlayabilir ve dolayısı ile komorbidite üzerindeki etkileri azaltılabilir.

Çıkar Çatışması Beyanı: Bu çalışmada çıkar çatışması yoktur.

Finansal Destek: Bu çalışma herhangi bir fon tarafından desteklenmemiştir.

Declaration of Conflicting Interests: There is no conflict of interest in thisstudy.

Financial Disclosure: No financial support was received.

\section{KAYNAKLAR}

1. Quasthoff S, Hartung HP. Chemotherapy-induced peripheral neuropathy. J Neurol. 2002; 249: 9-17.

2. Han Y, Smith MT. Pathobiology of cancer chemotherapy-induced peripheral neuropathy (CIPN). Front Pharmacol.2013; 18: 4: 156.

3. Argyriou AA, Kyritsis AP, Makatsoris T, Kalofonos HP. Chemotherapy-induced peripheral neuropathy in adults: a comprehensive update of the literature. Cancer Manag Res. 2014; 6: 135-47.

4. Park SB, Goldstein D, Krishnan AV, et al. Chemotherapy-induced peripheral neurotoxicity: A critical analysis. CA Cancer J Clin. 2013; 63: 419-37.

5. Al-Atiyyat N, Obaid A. Management of peripheral neuropathy induced by chemotherapy in adults with cancer: a review. Int J Palliat Nurs. 2017 Jan 2; 23: 13-7.

6. Kerckhove N, Pereira B, Pezet D, Balayssac D. Clinicalassessment of new antineuropathic strategies for chemotherapy-induced peripheral neuropathy: pain should not be the principal endpoint. Pain. 2017; 158: $180-2$.

7. Cata JP, Weng HR, Burton AW, Villareal H, Giralt S, Dougherty PM. Quantitative sensory findings in patients with bortezomib-induced pain. J Pain. 2007 Apr; 8: 296-306.

8. Wilkes G. Peripheral neuropathy related to chemotherapy. Semin Oncol Nurs. 2007 Aug; 23: 16273.

9. Gutierrez-Gutierrez G, Sereno M, Miralles A, CasadoSaenz E, Gutierrez Rivas E. Chemotherapy-induced peripheral neuropathy: clinical features, diagnosis, prevention and treatment strategies. Clin. Transl. Oncol. 2010; 12: 81-91.

10. Seretny M, Currie GL, Sena ES, et all. Incidence, prevalence, and predictors of chemotherapyinduced peripheral neuropathy: a systematic review and metaanalysis. Pain. 2014; 155: 2461-70.

11. Dougherty PM, Cata JP, Cordella JV, Burton A, Weng HR. Taxol-induced sensory disturbance is characterized by preferential impairment of myelinated fiber function in cancer patients. Pain. 2004 May; 109: 132-42.

12. Johnson C, Pankratz VS, Velazquez AI, et all. Candidate pathway-based genetic association study of platinum and platinum-taxane related toxicity in a cohort of primary lung cancer patients. J. Neurol. Sci. 2015; 349: 124-8.

13. Paternostro-Sluga T, Grim-Stieger M, Posch M, et all. Reliability and validity of the Medical Research Council (MRC) scale and a modified scale for testing muscle strength in patients with radial palsy. J Rehabil Med. 2008 Aug; 40: 665-71.

14. Krishnan AV, Goldstein D, Friedlander M, Kiernan MC. Oxaliplatin-induced neurotoxicity and the development of neuropathy. Muscle Nerve. 2005; 32: 51-60.

15. Rowinsky EK, Chaudhry V, Cornblath DR, Donehower RC. Neurotoxicity of Taxol. J Natl Cancer Inst Monogr. 1993; 15: 107-15.

16. Reyes-Gibby CC, Morrow PK, Buzdar A, Shete S. Chemotherapy-induced peripheral neuropathy as a predictor of neuropathic pain in breast cancer patients previously treated with pacliaxel. J Pain 2009; 10: 1146-50.

17. Kolb NA, Smith AG, Singleton JR, et all. The Association of Chemotherapy-Induced Peripheral Neuropathy Symptoms and the Risk of Falling. JAMA Neurol. 2016; Jul 1; 73: 860-6.

18. Ganz DA, Bao Y, Shekelle PG, Rubenstein LZ. Will my patient fall? JAMA. 2007; 297: 77-86.

19. Strumberg D, Brugge S, Korn MW, et all. Evaluation of long-term toxicity in patients after cisplatinbased chemotherapy for non seminomatous testicular cancer. Ann. Oncol.2002; 13: 229-36.

20. Hile ES, Fitzgerald GK, Studenski SA. Persistent mobility disability after neurotoxic chemotherapy. Phys Ther. 2010 Nov; 90: 1649-57.

21. Gutiérrez-Gutiérrez G, Sereno M, Miralles A, CasadoSáenz E, Gutiérrez-Rivas E. Chemotherapy-induced peripheral neuropathy: clinical features, diagnosis, prevention and treatment strategies. Clin Transl Oncol. 2010 Feb; 12: 81-91. 
22. Fernandes R, Mazzarello S, Hutton B, et all. Taxane acute pain syndrome (TAPS) in patients receiving taxane-based chemotherapy for breast cancer-a systematic review. Support. Care Cancer. 2016; 24: 3633-50.

23. Loprinzi CL, Maddocks-Christianson K, Wolf SL, et all. The Paclitaxel acute pain syndrome:sensitization of nociceptors as the putative mechanism. Cancer J. 2007; 13: 399-403.

24. Loprinzi CL, Reeves BN, Dakhil SR, et all. Natural history of paclitaxel-associated acute pain syndrome: prospective cohort study NCCTG N08C1. J Clin Oncol. 2011; 29: 1472-8.

25. Amptoulach, S., and Tsavaris, N. Neurotoxicity caused by the treatment with platinum analogues. Chemother. Res. Pract. 2011; 2011: 843019.
26. Wolf S, Barton D, Kottschade L, Grothey A, Loprinzi C. Chemotherapy-induced peripheral neuropathy: prevention and treatment strategies. Eur J Cancer. 2008; 44: 1507-15.

27. Monfort SM, Pan X, Patrick R, et all. Gait, balance, and patient-reported outcomes during taxane-based chemotherapy in early-stage breast cancer patients. Breast Cancer Res Treat. 2017 Jul; 164: 69-77.

28. Koike H, Tanaka F, Sobue G. Paraneoplastic neuropathy: wide-ranging clinicopathological manifestations. Curr Opin Neurol. 2011; 24: 504-10.

29. Raspotnig M, Vedeler C, Storstein A. Paraneoplastic neurological syndromes in lung cancer patients with or without onconeural antibodies. J Neurol Sci. 2015; 15: 348: 41-5. 